\title{
PEMBERDAYAAN KELOMPOK IBU RUMAH TANGGA: PELATIHAN PEMBUATAN SABUN DARI MINYAK GORENG BEKAS MENJADI HOME INDUSTRI
}

\section{HOUSEHOLD GROUP EMPOWERMENT: SOAP-MAKING TRAINING USING USED COOKING OIL FOR HOME INDUSTRY}

\author{
${ }^{1 *}$ Fatma Nuraisyah, ${ }^{2)}$ Rochana Ruliyandari \\ ${ }^{1}$ Program Studi Ilmu Kesehatan Masyarakat, Fakultas Kesehatan Masyarakat \\ ${ }^{2}$ Pusat Studi Dinamika Sosial, Universitas Ahmad Dahlan \\ Universitas Ahmad Dahlan \\ Kampus 3, Jalan Prof. Dr. Soepomo, S.H. Janturan Yogyakarta 55164 \\ *Email: fatma.nuraisyah@ikm.uad.ac.id
}

\begin{abstract}
ABSTRAK
Tujuan dari kegiatan pengabdian pada masyarakat ini adalah untuk menambah pengetahuan serta keterampilan ibu rumah tangga dalam mengolah minyak jelantah yang merupakan limbah menjadi produk yang bermanfaat yaitu sabun. Metode yang digunakan adalah penyuluhan, pelatihan, dan pendampingan. Capaian yang diperoleh dari kegiatan pengabdian adalah kelompok ibu rumah tangga mampu membuat dan mengolah sabun dari minyak jelantah/bekas menjadi aneka bentuk dengan kreasi masing-masing sehingga bernilai ekonomi serta menambah pendapatan rumah tangga.
\end{abstract}

Kata kunci: Minyak Jelantah; Pelatihan; Sabun

\section{ABSTRACT}

This community service aimed to increase housewives' knowledge and skills in processing used cooking oil into a more beneficial product: soap. The methods used were counseling, training, and mentoring. This community service's achievement was that the housewives group could make and process soap from used cooking oil into various forms or shapes using their creativities so that the used cooking oil had economic value and the household income was increased.

Keywords: Used Cooking Oil; Training; Soap

Submitted : 14 Februari 2020 Revision : 27 September 2020 Accepted : 29 Maret 2021

\section{PENDAHULUAN}

Kondisi kesehatan nasional sedang tidak stabil belakangan ini, dikarenakan pandemik covid-19 (Pakar \& Tugas, 2020) dan kebutuhan sehari-hari terus meningkat. Hal tersebut tidak dapat dihindari berpeluang memicu permasalahan baru di kalangan keluarga menengah ke bawah misalnya masalah kesehatan lingkungan, krisis ekonomi, krisis kesehatan mental dan lain-lain. Masalah lingkungan bisa berupa sampah anorganik yang tidak dapat diurai oleh bakteri (Yuliana
\& Wijayanti, 2019). Dengan keterampilan khusus, sampah anorganik dan organik yang berasal dari aktivitas rumah tangga dapat diolah menjadi barang-barang yang bermanfaat dan dapat bernilai ekonomi, sehingga dapat menambah income bagi keluarga (Aryenti, 2011). Sampah anorganik bisa menjadi bencana jika tidak dikendalikan penggunaannya terutama di kalangan rumah tangga (Yuliana \& Wijayanti, 2019). Limbah minyak goreng dapat diolah menjadi sabun cuci piring yang ramah lingkungan 
(Handayani, et al., 2020; Kusumaningtyas, Qudus, \& Kusumawardani, 2018).

Salah satu sampah rumah tangga yang ikut berkontribusi dapat merusak lingkungan yaitu minyak jelantah/ minyak bekas. Dengan demikian masyarakat perlu dikenalkan ide kreatif/inovasi dalam rangka meminimalisir limbah rumah tangga terutama yang berpotensi merusak lingkungan. Dengan kondisi ini, bisa menjadi peluang bagi ibu-ibu rumah tangga untuk menjadi lebih produktif yang mampu menciptakan/ menghasilkan barang bekas/ sampah menjadi barang yang bernilai ekonomi. Salah satunya adalah pembuatan sabun dari minyak goreng bekas. Tak jarang minyak goreng bekas selalu dibuang ibu-ibu. Apabila minyak goreng tersebut dibuang di sembarang tempat, maka berpotensi merusak lingkungan sekitar. Sementara itu, minyak goreng tersebut bisa diolah lagi menjadi sabun yang dapat bernilai ekonomi. Tujuan dari kegiatan pengabdian ini yaitu:

1. Meningkatkan pengetahuan tentang inovasi tepat guna penggunaan minyak jelantah/minyak bekas menjadi sabun

2. Melatih ibu-ibu rumah tangga dalam membuat sabun berbahan dasar minyak goreng bekas/minyak jelantah.

3. Sebagai stimulasi Usaha Kecil Menengah (UMKM) Mandiri produk yang berlebihan bisa dijual ke pasar bebas untuk menambah pendapatan tambahan keluarga.

\section{METODE}

Metode yang digunakan dalam kegiatan pengabdian ini yaitu:

1. Pretest kemudian dilanjutkan dengan penyuluhan/edukasi tentang manfaat dari limbah minyak goreng bekas.

2. Focus Group Discussion (FGD) disampaikan cara pembuatan sabun dari minyak bekas.

3. Pelatihan pembuatan sabun dari minyak bekas/jelantah yang dipandu oleh mentor.

4. Posttest dan evaluasi kegiatan.

Kegiatan pengabdian ini dilaksanakan di Desa Ambarketawang dengan peserta ibu-ibu rumah tangga.

\section{HASIL DAN PEMBAHASAN}

Kegiatan pengabdian ini memberikan pengetahuan tentang pemanfaatan limbah jelantah kepada ibu-ibu rumah tangga peserta kegiatan. Pengetahuan diberikan melalui kegiatan penyuluhan (gambar 1). Berdasarkan hasil evaluasi yang dilakukan selama kegiatan, diketahui adanya perubahan nilai rerata pengetahuan sebelum diberi penyuluhan 5,50 menjadi 7,90 setelah diberi penyuluhan. Hal tersebut menunjukkan bahwa kegiatan ini cukup berhasil sesuai dengan tujuan yang diharapkan.

Kelompok ibu-ibu rumah tangga peserta kegiatan sangat antusias dengan adanya model kerajinan yang lebih kreatif dan bernilai ekonomi yang dihasilkan dari pengolahan limbah jelantah (Gambar 2).

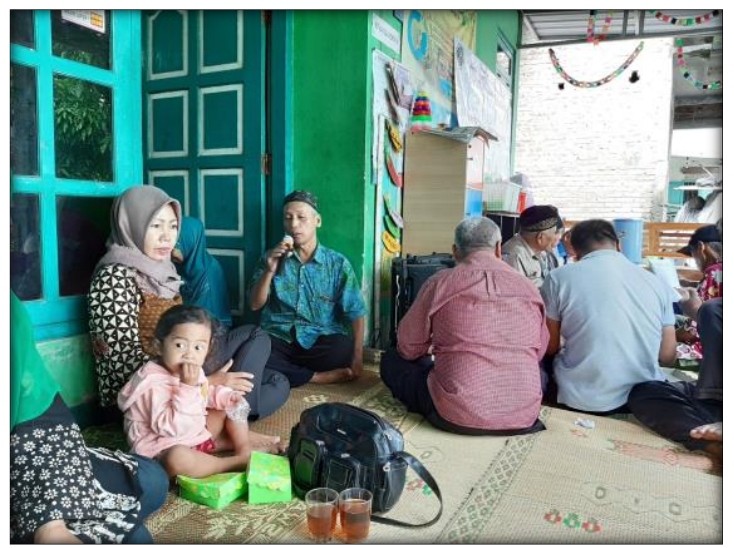

Gambar 1. Kegiatan Penyuluhan dan pengenalan cara membuat sabun dari minyak jelantah

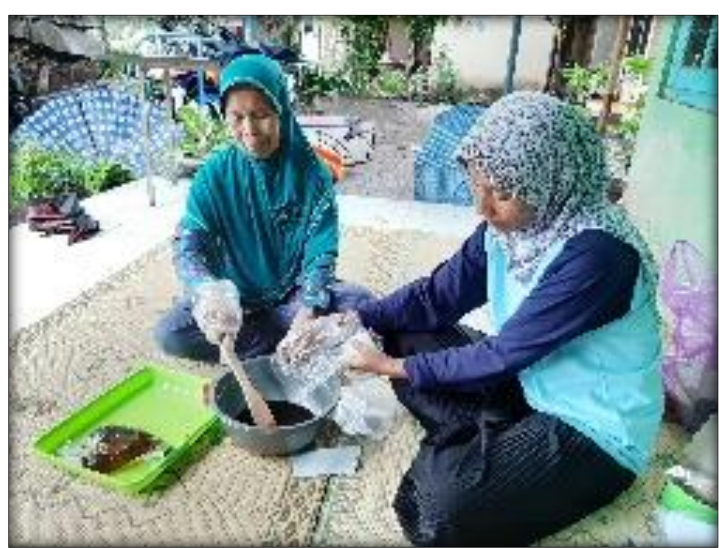


Gambar 2. Peserta antusias untuk

mempraktekkan pembuatan sabun dari minyak jelantah

Hasil dari kegiatan pengabdian ini dapat menjadi stimulasi peningkatan keterampilan ibu-ibu rumah tangga untuk menjadi lebih produktif dan memberikan nilai tambah dari bahan yang awalnya dapat dikategorikan sebagai limbah. Selain itu, produk yang dibuat dapat digunakan untuk dijual sebagai souvenir atau bisa digunakan untuk keperluan sehari-hari misalnya untuk mandi, cuci piring, cuci pakaian, dan lain-lain yang ramah lingkungan. Pengetahuan sangat penting untuk mendorong munculnya ide-ide yang bervariasi (Yudha, 2017). Upaya pengolahan limbah jelantah ini juga turut mendukung upaya pelestarian lingkungan yaitu dengan mengurangi pembuangan limbah rumah tangga ke lingkungan.

\section{SIMPULAN}

Berdasarkan kegiatan pengabdian yang telah dilaksanakan, terdapat perubahan pengetahuan dan sikap antusias selama kegiatan pelatihan dari ibu-ibu rumah tangga peserta kegiatan. Dengan adanya kegiatan ini, diharapkan sebagai stimulasi ibu-ibu rumah tangga mampu memproduksi sabun dari minyak jelantah lebih variatif dan mampu memproduksi serta mempromosikan secara mandiri hasil kerajinan sehingga dimungkinkan dapat berkontribusi memperbaiki perekenomian rumah tangga.

\section{DAFTAR PUSTAKA}

Aryenti. (2011). Peningkatan Peranserta Masyarakat Melalui Gerakan Menabung Pada Bank Sampah Di Kelurahan Babakan Surabaya, Kiaracondong Bandung. Jurnal Permukiman, 6(1), 4046.

Handayani, D., Yulianto, ME., Siswanto AP., Kusumayanti H, Pujiastuti A, Jannah R, \& Berdiansyah S. (2020). Pelatihan Pembuatan Sabun Dari Minyak Goreng Bekas di Desa Kangkung, Kecamatan Mranggen, Kabupaten Demak. Jurnal Pengabdian Vokasi, 01(03). Retrieved from

https://ejournal2.undip.ac.id/index.php/jp v/article/view/7873/4064

Kusumaningtyas, R. D., Qudus, N., \& Kusumawardani, Rr. D. A. P. (2018). Penerapan Teknologi Pengolahan Limbah Minyak Goreng Bekas Menjadi Sabun Cuci Piring Untuk Pengendalian Pencemaran Dan Pemberdayaan Masyarakat. Jurnal Abdimas, 22(2). Retrieved from https://journal.unnes.ac.id/nju/index.php/ abdimas/article/view/16587

Pakar, T., \& Tugas, G. (2020). Menuju Tahapan Indonesia Produktif dan Aman COVID-19.

Yudha, F. (2017). Pelatihan Pembuatan Kerajinan Berbahan Plastik Bekas. Jurnal Pengabdian Dan Pemberdayaan Masyarakat, 1(1). Retrieved from http://jurnalnasional.ump.ac.id/index.php /JPPM/article/view/1200/1249

Yuliana, I., \& Wijayanti, Y. (2019). Partisipasi Masyarakat pada Program Bank Sampah. Higeia Journal of Public Health Research and Development, 3(4), 84-94. 